\title{
Radostaw Kuca*
}

\section{ROLA NARZĘDZI IT W STRATEGII ZARZĄDZANIA UCZELNIĄ WYŻSZĄ}

Z a ry s tre ś c i: W artykule zawarta jest analiza dokumentów strategicznych uczelni wyższych wykonana pod kątem zmiany sposobu zarządzania tego rodzaju instytucjami, opisana jest rola rankingów szkół wyższych w tym procesie oraz wskazane są istniejące oraz projektowane narzędzia komputerowe służące do kontroli danych zarządczych. Celem artykułu jest omówienie zastosowania narzędzi IT (standardowych oraz zindywidualizowanych) dedykowanych do gromadzenia oraz analizy danych zarządczych, w procesie zarządzania uczelnią wyższą.

S ł o w a k l u c z o w e: Rankingi szkół wyższych, zarządzanie instytucją szkolnictwa wyższego, narzędzia informatyczne wspomagające zarządzanie uczelnią wyższą, dane zarządcze w uczelni wyższej.

K 1 a s y fik a c j J E L: L 21

\section{WSTĘP}

Szkolnictwo wyższe w Polsce można opisywać i klasyfikować przyjmując różne kryteria: historyczne, geograficzne, dziedzinowe czy jakościowe. $\mathrm{Na}$ potrzeby niniejszego artykułu Autor nie zagłębiał się w definicje szkolnictwa wyższego sensu stricto, a przyjął jedynie podział i klasyfikację opartą na klasyfikacji zaproponowanej przez twórców miarodajnego rankingu szkół wyższych w Polsce - rankingu „Perspektywy”. W artykule odwołał się do dokumentów strategicznych wyznaczających standardy zarządzania uczelniami na najbliższe dziesięć lat, przybliżył i krótko opisał istniejące oraz proponowane narzędzia,

\footnotetext{
* Adres do korespondencji: Radosław Kuca, Górnośląska Wyższa Szkoła Handlowa im. Wojciecha Korfantego w Katowicach, Wydział Zarządzania, ul. Harcerzy Września 1939 3, 40-659 Katowice, e-mail: radek.kuca@gmail.com;
} 
które mogą wspomagając procesy zarządzania instytucjami szkolnictwa wyższego.

Rysunek 1. Klasyfikacja szkół wyższych według rankingu „Perspektywy” wraz z kryteriami branymi pod uwagę $\mathrm{w}$ zestawieniu.

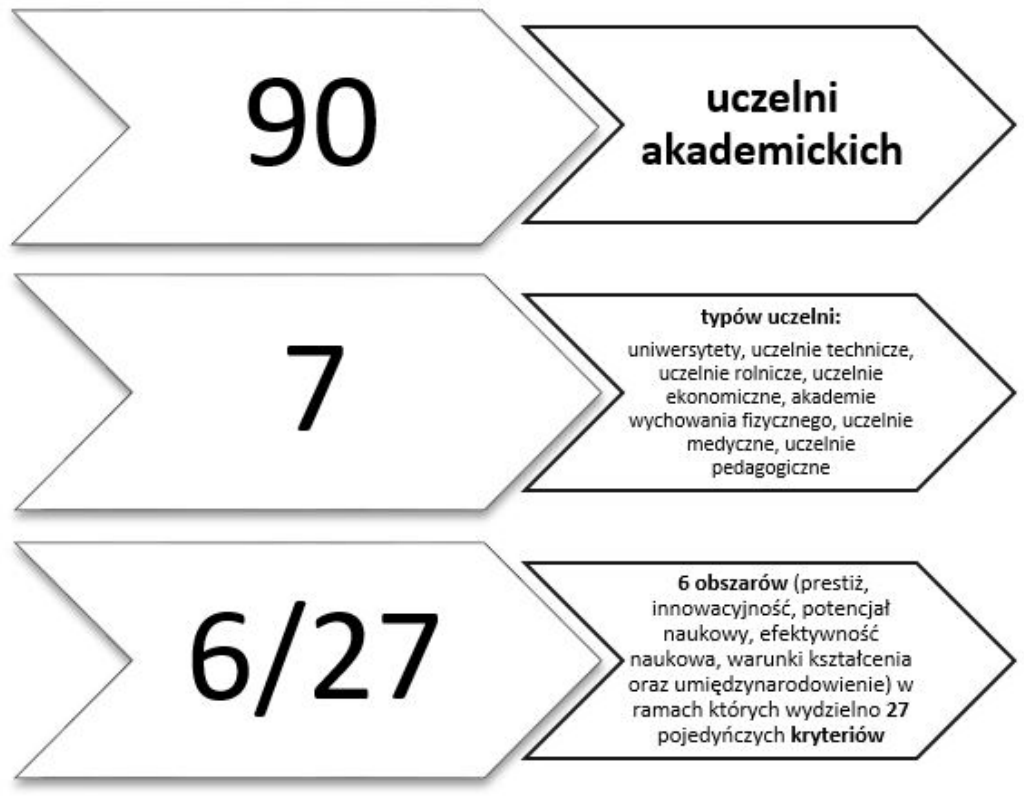

Źródło: opracowanie własne.

\section{STRATEGIE ROZWOJU UCZELNI}

Wraz z nowelizacją ustawy „Prawo o szkolnictwie wyższym”, która weszła w życie 1 października 2011 roku, w art. 66 ust. 1a pojawił się następujący zapis: „Rektor opracowuje i realizuje strategię rozwoju uczelni, uchwalaną przez organ kolegialny uczelni wskazany w statucie". Ten mało widoczny zapis zapoczątkował trend do tworzenia strategii uczelni podobnych do strategii tworzonych dla korporacji. Większość z nich wskazuje konieczność urynkowienia działań (na skalę instytucji szkolnictwa wyższego, przy zachowaniu podstawowej misji), bycia konkurencyjnym na rynku szkolnictwa wyższego czy bezpośrednio lub pośrednio nakazuje zmianę modelu zarządzania. 
Tabela 1. Przegląd strategii dla 10 najlepszych uczelni akademickich wg rankingu Perspektywy 2016

\begin{tabular}{|c|c|c|c|}
\hline Nazwa uczelni & $\begin{array}{l}\text { Czy uczel- } \\
\text { nia posiada } \\
\text { strategię } \\
\text { rozwoju }\end{array}$ & Nazwa strategii rozwoju & $\begin{array}{c}\text { Data uchwalenia lub } \\
\text { przyjęcia }\end{array}$ \\
\hline Uniwersytet Warszawski & TAK & $\begin{array}{l}\text { „Strategia średniotermino- } \\
\text { wa uniwersytetu warszaw- } \\
\text { skiego na lata 2014-2018” }\end{array}$ & 25 czerwca 2014 r. \\
\hline Uniwersytet Jagielloński & TAK & $\begin{array}{l}\text { "Strategia Rozwoju Uniwer- } \\
\text { sytetu Jagiellońskiego w } \\
\text { latach 2014-2020" }\end{array}$ & 2014 \\
\hline $\begin{array}{l}\text { Uniwersytet im. Adama Mickiewi- } \\
\text { cza w Poznaniu }\end{array}$ & TAK & $\begin{array}{l}\text { "Strategia rozwoju uniwer- } \\
\text { sytetu im. Adama Mickie- } \\
\text { wicza w poznaniu na lata } \\
\text { 2009-2019" }\end{array}$ & $\begin{array}{l}\text { czerwiec 2009/ noweli- } \\
\text { zacja: listopad } 2013\end{array}$ \\
\hline Politechnika Warszawska & TAK & $\begin{array}{c}\text { "Strategia rozwoju Politech- } \\
\text { niki Warszawskiej do roku } \\
\text { 2020" }\end{array}$ & 23 lutego $2011 \mathrm{r}$. \\
\hline Politechnika Wrocławska & TAK & $\begin{array}{l}\text { „Strategia Politechniki } \\
\text { Wrocławskiej” }\end{array}$ & 21 marca $2013 \mathrm{r}$. \\
\hline $\begin{array}{l}\text { Akademia Górniczo-Hutnicza im. } \\
\text { Stanisława Staszica w Krakowie }\end{array}$ & TAK & $\begin{array}{l}\text { „strategia rozwoju } \\
\text { Akademii Górniczo Hutni- } \\
\text { czej im. Stanisława Staszi- } \\
\text { ca w Krakowie” }\end{array}$ & 25 stycznia 2017 r. \\
\hline Uniwersytet Wrocławski & TAK & $\begin{array}{l}\text { „Strategia rozwoju Uni- } \\
\text { wersytetu Wrocławskiego } \\
\text { 2013-2020" }\end{array}$ & 26 czerwca 2013 r. \\
\hline $\begin{array}{l}\text { Warszawski Uniwersytet Me- } \\
\text { dyczny }\end{array}$ & TAK & $\begin{array}{l}\text { "System Zarządzania } \\
\text { Jakością Kształcenia } \\
\text { Warszawskiego Uniwersy- } \\
\text { tetu Medycznego" }\end{array}$ & 23 lutego $2015 \mathrm{r}$. \\
\hline Gdański Uniwersytet Medyczny & NIE & - & - \\
\hline $\begin{array}{l}\text { Uniwersytet Mikołaja Kopernika } \\
\qquad \text { w Toruniu }\end{array}$ & TAK & $\begin{array}{l}\text { "Strategia Rozwoju Uniwer- } \\
\text { sytetu Mikołaja Kopernika } \\
\text { na lata } 2011 \text { - 2020" }\end{array}$ & 15 kwietnia 2014 r. \\
\hline
\end{tabular}

Źródło: Opracowanie własne na podstawie materiałów strategicznych uczelni.

W większości z dokumentów opisanych w Tabeli 1. można znaleźć zalecenia nakazujące wdrożenie nowoczesnych systemów informatycznych służących do racjonalnego zaradzania uczelnią. Nowoczesne zarządzanie oparte na wiedzy oraz nowoczesnych narzędziach ma być rozwiązaniem problemów, z którymi boryka się większość uczelni w Polsce. Analizując oficjalne dokumenty prezen- 
tujące strategię trzech $\mathrm{z}$ pośród pięciu najlepszych uczelni $\mathrm{w}$ Polsce ${ }^{1}$ możemy znaleźć między innymi takie cytaty:

- Politechnika Warszawska: Do roku 2020 Politechnika Warszawska będzie uczelnią, która: „dysponuje w pełni zintegrowanym systemem informatycznym wspomagającym zarzadzanie", Efektywność organizacji pracy administracji centralnej, wydziałowej oraz innych jednostek organizacyjnych będzie zwiększona dzięki między innymi „wprowadzeniu mechanizmów stałego podnoszenia jakości procesów organizacyjnych, odwołujących się do metod zarzadzania jakością i zarzadzania problemami; pełnej informatyzacji procesu zarzadzania, a w szczególności wprowadzenie elektronicznego obiegu dokumentów oraz dzięki stworzeniu systemu sprawozdawczości zarządczej”.

- Uniwersytet Jagielloński: Uczelnia w celu poprawy efektywności działania, wykorzystując własne wyjątkowe zasoby ,planuje na lata 2014-2020 rozbudowę zintegrowanego systemu informatycznego, wspierającego działalność Uczelni we wszystkich możliwych wymiarach - dydaktyki, nauki oraz utrzymywania relacji ze środowiskiem zewnętrznym".

- Uniwersytet Warszawski: Uczelnia jako jeden ze swoich priorytetów wskazuje informatyzację. Do najważniejszych zadań w tym zakresie zalicza: Portal Wewnętrzny Uniwersytetu Warszawskiego, który opisuje jako narzędzie „którego głównym celem ma być zapewnienie pracownikom i studentom dostępu do nowoczesnych narzędzi pracy (naukowej, dydaktycznej, organizacyjnej) zgodnych ze światowymi standardami akademickimi. Pozwoli on na integrację i lepsze wykorzystanie coraz większych zasobów elektronicznych UW, a także wymusi reformę systemu obiegu informacji na UW i doprowadzi do uporządkowania procedur i przepisów obowiązujących na Uczelni” oraz informatyzację zarzadzania uczelnią, którą rozumie jako „zwiększenie funkcjonalności i zintegrowania informatycznych systemów zarzadzania kadrami i gospodarką finansową Uniwersytetu". Ostatnim zadaniem jest system zarzadzania uczelnią, w którym jednym z kluczowych działań jest „Usprawnienie systemu obiegu informacji poprzez integrację i zwiększenie funkcjonalności działających systemów informatycznych (USOS, HMS) oraz utworzenie zintegrowanego systemu informatycznego (Portalu Wewnętrznego)".

\footnotetext{
${ }^{1}$ Na podstawie rankingu Perspektywy 2016
} 


\section{RANKINGI SZKÓŁ WYŻSZYCH}

We współczesnym szkolnictwie wyższym coraz większą rolę zaczynają odgrywać rankingi. Są one coraz ważniejszym czynnikiem wpływającym na wizerunek uczelni, budującym ich markę oraz świadczących o ich jakości. To informacje chętnie wykorzystywane przez uczelnie w przekazach promocyjnych i reklamowych. Umożliwiają łatwe porównywanie zarówno całych uczelni, jak i konkretnych aspektów ich funkcjonowania.

Rankingi to źródło użytecznej wiedzy dla władz uczelni, ale należy pamiętać, że nie powinny służyć one jako jedyne źródło informacji o stanie instytucji. Ich wyników nie można traktować jako ,prawdy ostatecznej” i interpretować wyłącznie w kategoriach awans = sukces, spadek = porażka.

Chęć zarzadzania uczelnią w taki sposób, żeby w najbliższej dekadzie znalazła się ona na lepszej pozycji w rankingach szkół wyższych ma wpisane do swojej strategii sześć uczelni z pierwszej dziesiątki uczelni w Polsce. W tej grupie wyjątkiem są uczelnie medyczne.

Tabela 2. Przegląd cytatów dotyczących obecności uczelni w rankingach instytucji szkolnictwa wyższego dla sześciu najwyżej klasyfikowanych uczelni wyższych wraz ze skróconą metryczką

\begin{tabular}{|c|c|c|}
\hline Nazwa uczelni & $\begin{array}{c}\text { Dane podstawowe (liczba } \\
\text { studentów oraz liczba } \\
\text { wydziałów) }\end{array}$ & $\begin{array}{l}\text { Cytat zawarty w strategii rozwoju uczelni } \\
\text { (lub dokumencie odpowiadającym) }\end{array}$ \\
\hline \multirow{3}{*}{$\begin{array}{l}\text { Uniwersytet Warszaw- } \\
\text { ski }\end{array}$} & Liczba studentów: 51200 & \multirow{3}{*}{$\begin{array}{c}\text { „Cel: Tworzenie korzystnych relacji z otocze- } \\
\text { niem zewnętrznym, Wzmocnienie pozycji } \\
\text { i wizerunku Uniwersytetu Warszawskiego [co } \\
\text { w domyśle ma doprowadzić do] Wzmocnienie } \\
\text { pozycji Uniwersytetu w rankingach". }\end{array}$} \\
\hline & Liczba wydziałów: 21 & \\
\hline & Stan na rok 2016 & \\
\hline \multirow{3}{*}{$\begin{array}{l}\text { Uniwersytet Jagiel- } \\
\text { loński }\end{array}$} & Liczba studentów: 43405 & \multirow{3}{*}{$\begin{array}{c}\text { "Uniwersytet Jagielloński osiagnął } \\
\text { trwała pozycję } \\
\text { w światowej czołówce ośrodków akademickich } \\
\text { w badaniach, nauczaniu i transferze wiedzy". }\end{array}$} \\
\hline & Liczba wydziałów: 16 & \\
\hline & Stan na dzień 31/12/2015 r. & \\
\hline \multirow{3}{*}{$\begin{array}{l}\text { Uniwersytet im. Adama } \\
\text { Mickiewicza w Po- } \\
\text { znaniu }\end{array}$} & Liczba studentów: 43422 & \multirow{3}{*}{$\begin{array}{l}\text { „Pragniemy, by w roku 2019, obchodząc swoje } \\
\text { 100-lecie, Uniwersytet im. Adama Mickiewicza } \\
\text { w Poznaniu był uczelnia, która jest jednym } \\
\text { z czołowych uniwersytetów w Europie, obec- } \\
\text { nym w światowych rankingach, o wysokim } \\
\text { poziomie i innowacyjności badań, przyjaznym } \\
\text { studentowi, sprawnie zarządzanym, słynącym } \\
\text { z tolerancji, otwartości i różnorodności; jest au- } \\
\text { torytetem w życiu społecznym, gospodarczym } \\
\text { i politycznym kraju”. }\end{array}$} \\
\hline & Liczba wydziałów: 15 & \\
\hline & Stan na dzień 30/11/2015 r. & \\
\hline
\end{tabular}




\begin{tabular}{|c|c|c|}
\hline \multirow{3}{*}{$\begin{array}{c}\text { Politechnika Warszaw- } \\
\text { ska }\end{array}$} & Liczba studentów: 36092 & \multirow{3}{*}{$\begin{array}{l}\text { „Politechnika Warszawska powinna dażyć do } \\
\text { statusu uczelni badawczej, w której są prowa- } \\
\text { dzone badania naukowe na światowym pozio- } \\
\text { mie, a kształcenie studentów i doktorantów jest } \\
\text { powiązane bezpośrednio z tymi badaniami. To } \\
\text { właśnie kadra, studenci i doktoranci maja wpro- } \\
\text { wadzić naukę uprawiana na Uczelni w obieg } \\
\text { międzynarodowy i doprowadzić do tego, by } \\
\text { nasza Uczelnia znacząco awansowała } \\
\text { w światowych rankingach”. } \\
\text { „Oznacza to, że dażymy do tego, aby w roku } \\
2020 \text { Politechnika Warszawska była uczelnią } \\
\text { która w sposób zaplanowany uczestniczy } \\
\text { w rywalizacji międzynarodowej i w rankingach } \\
\text { światowych jest wśród pierwszych trzystu } \\
\text { uczelni” } \\
\text { „Celem jest zwiększenie rozpoznawalności } \\
\text { Uczelni na świecie, podniesienie jej pozycji } \\
\text { w rożnego rodzaju rankingach, wykreowanie } \\
\text { pozytywnej wiedzy odbiorcy o poziomie ofero- } \\
\text { wanych usług edukacyjnych i naukowych”. }\end{array}$} \\
\hline & $\begin{array}{l}\text { Liczba wydziałów: } 19 \text { wy- } \\
\text { działów + } 1 \text { Kolegium }\end{array}$ & \\
\hline & $\begin{array}{c}\text { Stan na rok akademicki } \\
2015 / 2016\end{array}$ & \\
\hline \multirow{3}{*}{$\begin{array}{l}\text { Politechnika Wrocław- } \\
\text { ska }\end{array}$} & Liczba studentów: 34964 & \multirow{3}{*}{$\begin{array}{l}\text { „Politechnika Wrocławska jest czołowym ośrod- } \\
\text { kiem naukowym i dydaktycznym w Polsce oraz } \\
\text { znaczącym ośrodkiem w UE. Pro I i jakość } \\
\text { kształcenia zapewniają jej odpowiednie miejsce } \\
\text { w międzynarodowych rankingach uczelni”. }\end{array}$} \\
\hline & Liczba wydziałów: 16 & \\
\hline & $\begin{array}{c}\text { Stan na rok akademicki } \\
2015 / 2016 \\
\end{array}$ & \\
\hline \multirow{3}{*}{$\begin{array}{c}\text { Akademia Górniczo- } \\
\text {-Hutnicza im. Stanisła- } \\
\text { wa Staszica } \\
\text { w Krakowie }\end{array}$} & Liczba studentów: 31956 & \multirow{3}{*}{$\begin{array}{l}\text { Jednym z najważniejszych celów Akademii } \\
\text { Górniczo - Hutniczej w zakresie nauki i innowa- } \\
\text { cji jest „osiagniecie wysokiej pozycji w świato- } \\
\text { wych rankingach dotyczących poziomu badań } \\
\text { naukowych i innowacyjności oraz uzyskanie } \\
\text { wyróżniających ocen w kategoryzacji polskich } \\
\text { jednostek naukowych”. }\end{array}$} \\
\hline & Liczba wydziałów: 16 & \\
\hline & Stan na dzień 30/10/2016 r. & \\
\hline
\end{tabular}

Zródło: Opracowanie własne na podstawie materiałów strategicznych oraz informacji ze stron internetowych uczelni.

Ważniejsze wydaje się sprawdzenie liczby punktów i porównywanie wyniku z ubiegłymi latami oraz z uczelniami o podobnym profilu (like to like). Szczególnie istotne jest zwracanie uwagi na kluczowe (najwyżej punktowane) kryteria w każdym z rankingów. Wychodząc z takiego założenia można je traktować jako istotne źródło wiedzy o stanie uczelni, a informacje w nich zawarte wraz ze wspominanymi wcześniej systemami informatycznymi są potężnym narzędziem zarządczym, jakim dysponują władze uczelni. 


\section{NARZĘDZIA INFORMATYCZNE W ZARZĄDZANIU UCZELNIĄ WYŻSZĄ}

Przytoczone cytaty świadczą o bardzo dużej świadomości roli jaką odgrywają narzędzia IT w sprawnym, nowoczesnym i efektywnym zarządzaniu uczelnią wyższą. Władze uczelni przyznają, że żeby efektywnie zarządzać każdym z obszarów działalności nie wystarczy już pracować tak, jak do tej pory. Konieczne są narzędzia informatyczne wspomagające proces zarządzania, które upraszczając możemy podzielić na trzy grupy zaprezentowane na rysunku.

Rysunek 2. Grupy narzędzi informatycznych wspomagających proces zarządzania uczelnią. Opracowanie własne.

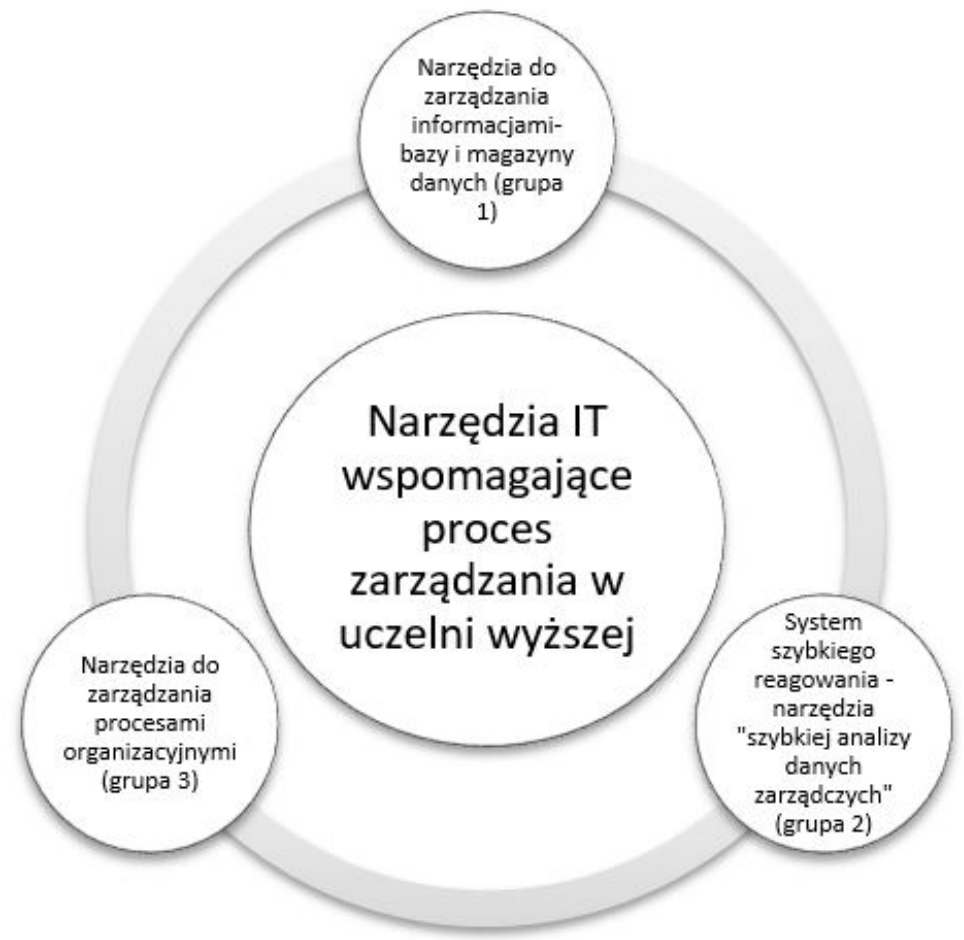

W każdej z grup narzędzi odpowiada za inny obszar wspomagający efektywne zarządzanie. W procesie zbierania danych potrzebnych do poszczególnych rankingów bardzo łatwo wyodrębnić słabe strony uczelni. Cykliczne zbieranie danych (gromadzonych przy pomocy narzędzi z grupy 1.) pozwala na przygotowanie zestawień analizowanych przez upoważnione osoby (przy pomocy narzędzi z grupy 2.), które są uwzględniane w nowych oraz istniejących już procesach zarządczych (narzędzia z grupy 3.). 
Wszystkie powyższe procesy i działania związane z zarządzaniem uczelnią mają odbicie $\mathrm{w}$ procesie zbierania $\mathrm{i}$ analizowania danych do rankingów oraz narzędziach do tego używanych.

Obecnie w Polsce istnieją dwie bazy danych, do których uczelnie podają swoje dane zarządcze. Są to POL-on oraz GUS.

Pierwsza z nich POL-on została stworzona i jest utrzymywana przez Ośrodek Przetwarzania Informacji - Państwowy Instytut Badawczy. System w założeniu ma dostarczać dane zarządcze, z 21 obszarów tematycznych, wspierające instytucje państwowe zajmujące się szkolnictwem wyższym - Ministerstwo Nauki i Szkolnictwa Wyższego (MNiSW), Centralną Komisje do spraw Stopni i Tytułów (CK) oraz Główny Urząd Statystyczny (GUS). Jest to globalna baza danych prezentująca dane zarówno publicznie, jak i jednostkom oraz osobom upoważnionym. W POL-onie gromadzone są informacje o wszystkich polskich jednostkach naukowych, do których publiczny dostęp wynika z rozporządzeń MNiSW. Z pośród 21 obszarów tematycznych 11 najważniejszych to:

- $\quad$ Podstawowe dane jednostek naukowych i uczelni wyższych.

- Rejestr uprawnień do nadawania stopni naukowych przez jednostki uczelni wyższych oraz instytuty badawcze i naukowe.

- Zestawienie uprawnień do prowadzenia studiów na określonym kierunku, poziomie i profilu kształcenia.

- Ogólnopolski wykaz studentów.

- Rejestr pracowników naukowych i nauczycieli akademickich.

- Sprawozdawczość uczelni.

- Wykaz działalności upowszechniających naukę.

- Rejestry nieruchomości, infrastruktury, laboratoriów i aparatury.

- Wykaz patentów i dokonań.

- Ankieta jednostki.

- System wyborczy CK.

Dodatkowo w systemie dostępna jest baza publikacji naukowych oraz wskaźniki ewaluacji szkół wyższych.

Druga z baz danych - GUS zawiera dane typowo statystyczne zgrupowane według właściwości i w przypadku szkolnictwa wyższego można je znaleźć w sześciu formularzach. Są to:

- Formularz F-01/s „Sprawozdanie o przychodach, kosztach i wyniku finansowym szkół wyższych" składany raz do roku.

- Formularz PNT-01/s „Sprawozdanie o działalności badawczej i rozwojowej $(\mathrm{B}+\mathrm{R})$ w szkołach wyższych składany raz do roku.

- Formularz PNT-05 „Sprawozdanie o działalności badawczej i rozwojowej w dziedzinie nanotechnologii w jednostkach naukowych" składany raz do roku o ile dotyczy.

- Formularz S-10 „Sprawozdanie o studiach wyższych” składany raz do roku. 
- Formularz S-11 „Sprawozdanie z pomocy materialnej i socjalnej dla studentów i doktorantów" składany raz do roku.

- Formularz S-12 „Sprawozdanie o stypendiach naukowych, studiach podyplomowych i doktoranckich oraz zatrudnieniu w szkołach wyższych, instytucjach naukowych i badawczych" składany raz do roku.

Obydwie bazy danych pomimo swej bardzo dużej szczegółowości nie są narzędziem, które pozwala ich pełne wykorzystanie jako narzędzia informatycznego wspierającego zarządzanie uczelnią wyższą. Rozwiązaniem może być model zakładający stworzenie własnej bazy danych o uczelni wykorzystywanej przy rankingach szkół wyższych, będącej jednocześnie wsparciem efektywnego zarządzania szkołą wyższą.

Narzędzie będzie pozwalało na zasysanie danych z istniejących baz danych (w sposób automatyczny lub ręczny) oraz będzie gromadziło w jednym miejscu i porządkowało dane już zbierane. Pozwoli to na szybkie zbieranie danych, generowanie różnego rodzaju zestawień (monitorujących stan uczelni), weryfikacje danych (pozbycie się skoków wielkości danych). Przy konstruowaniu takiego narzędzia konieczne jest powołanie zespołu osób odpowiedzialnych za wprowadzenie i gromadzenie danych, oraz stworzenie harmonogramu zbierania danych (np. raz na trzy miesiące) ustanowionego zarządzeniem JM Rektora. Udanym przykładem narzędzia integrującego szereg funkcji może być stworzenie na Uniwersytecie Mikołaja Kopernika w Toruniu Akademickiej Platformy Czasopism (apcz.pl). Jest ona wygodną platformą do publikowania artykułów, a dodatkowo pozwala na pobieranie lub eksport określonych danych do innych narzędzi (system antyplagiatowy iThenticate czy system POL-index) [Kopcewicz, 2016, s. 107]

W efekcie stworzenie serwisu zbierającego wszystkie niezbędne informacje o uczelni pozwoli na:

- Szybkie zbieranie danych.

- Generowanie różnego rodzaju zestawień (monitorujących stan uczelni).

- Weryfikacje danych (pozbycie się skoków wielkości danych).

Przykładowe działania wraz z podziałem na grupy przedstawione są na poniższym rysunku. 
Rysunek 3. Przykładowy schemat działań przy tworzeniu oraz wdrażaniu narzędzia informatycznego wspierającego zarządzanie uczelnią wyższą. Opracowanie własne

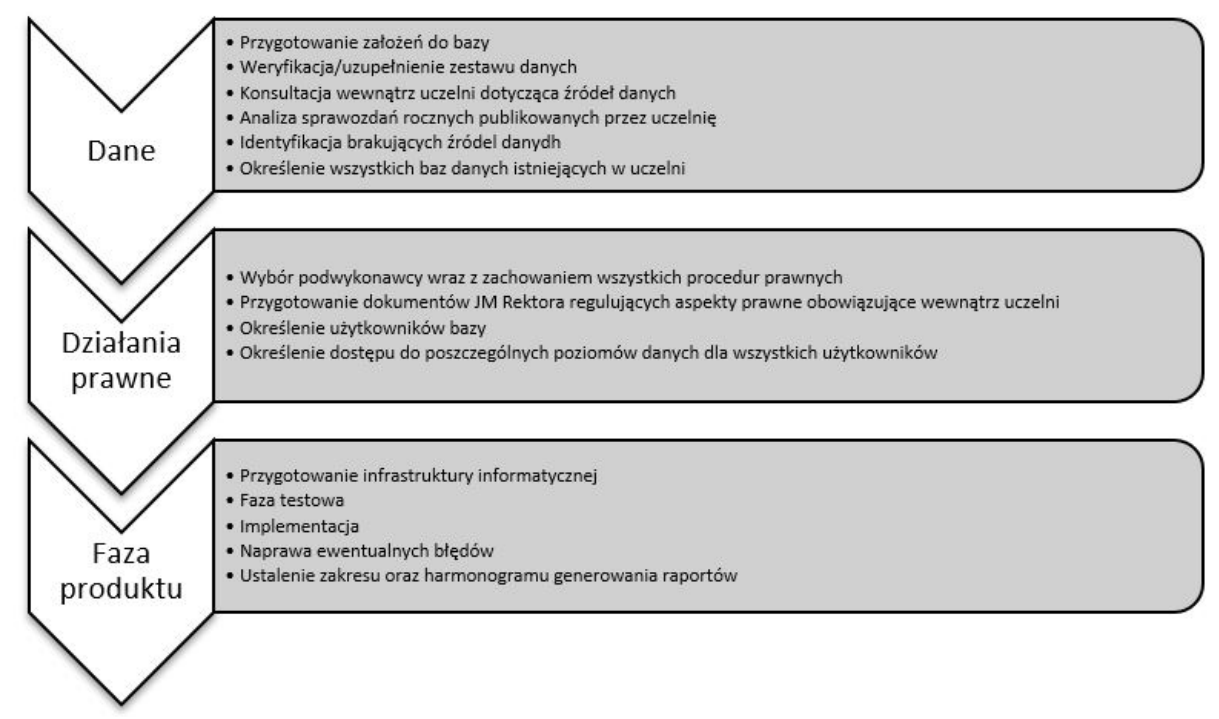

\section{PODSUMOWANIE}

Podsumowując artykuł niezbędne jest zaznaczenie, że uczelnie wyższe w XXI wieku podlegają takim samych prawom rynkowym jak wszystkie inne firmy i korporacje. Dlatego zmiana stylu zarządzania zaakcentowana w dokumentach strategicznych badanych uczelni wyższych jest niezbędna. W oparciu o współczesną wiedzę z dziedziny zarządzania wiemy, że jest możliwe jedynie przy wspomaganiu narzędziami IT. Bez względu na to, w jaki sposób będziemy klasyfikować uczelnie wyższe, co będziemy brali pod uwagę jako wskaźnik osiągniecia sukcesu, czy wskaźnik świadczący o jakości instytucji, będziemy się stykać z ogromną liczbą danych zarządczych. Do wyciągania prawidłowych wniosków oprócz wiedzy eksperckiej i mądrości władz uczelni niezbędne są narzędzia informatyczne pozwalające w łatwy sposób generować wszelkiego rodzaju analizy i zestawienia czy raporty, pozwalające na podejmowanie szybkich i trafnych decyzji strategicznych. 


\title{
LITERATURA
}

Blicharz J. (red.), (2014), Zarządzanie szkoła wyższa, http://www.bibliotekacyfrowa.pl/Content/63587/Zarzadzanie_szkola_wyzsza.pdf, [20.02.2017].

Delhaxhe A. (red.), (2009), Higher Education Governance in Europe: Policies, structures, funding and academic staff, Eurydice, Bruksela.

Flis M.-J. (przew. zesp.), (2014), „Strategia Rozwoju Uniwersytetu Jagiellońskiego w latach 2014-2020", http:/www.uj.edu.pl/documents/10172/84593596/Strategia-Rozwoju-UJ-2014-2020.pdf/f490b8e5-83f9-4509-9f9e-f88a1d89bd3c, [20.02.2017].

Gawroński R. (przew.), (2011), ,Strategia rozwoju Politechniki Warszawskiej do roku 2020”, Oficyna Wydawnicza PW, Warszawa.

Kopcewicz G., (2016), Akademicka Platforma Czasopism jako nowoczesne forum wymiany myśli naukowej, „AUNC Zarządzanie”, XLIII, nr 1/2016. http://apcz.umk.pl/czasopisma//index.php/AUNC_ZARZ/article/view/AUNC_ ZARZ.2016.007, [20.02.2017].

Leja K., (2013), Zarządzanie uczelnia. Koncepcje i wspótczesne wyzwania, Wolters Kluwer Polska SA, Warszawa.

Schroeder W. (przew.), (2013), Strategia rozwoju uniwersytetu im. Adama Mickiewicza w Poznaniu na lata 2009-2019, https://amu.edu.pl/_data/assets/pdf_file/0004/239755/STRATEGIA-ROZWOJU-UAM_NOWELIZACJA.pdf, [20.02.2017].

du Valla M. (red.), (2010), Modele zarzadzania uczelniami w Polsce, UJ Centrum Badań nad Szkolnictwem Wyższym, http://www.nauka.gov.pl/g2/oryginal/2013_05/bdfa51cb239812bbeac12dfa59be461c.pdf, [20.02.2017].

Strony internetowe Politechniki Wrocławskiej, Akademii Górniczo-Hutniczej oraz innych uczelni wymienianych w artykule.

\section{IMPORTANCE OF IT SOLUTIONS FOR HEI STRATEGIC MANAGEMENT}

\begin{abstract}
The article analyzes the strategic documents of HEI (higher education institutions) in terms of the change in the management process of such institutions, describes the role of HEI rankings, identifies existing and planned IT tools as a necessary part of strategic management plan.
\end{abstract}

Keywords: HEI rankings, HEI management, IT tools to support HEI management, data management in HEI. 
